\title{
Working Capital Optimization in Supply Chains ${ }^{1}$
}

\author{
Nikolay Zenkevich \\ St. Petersburg State University \\ 3 Volkhovsky Ln, St. Petersburg, Russia \\ E-mail: zenkevich@gsom.pu.ru

\section{Anastasiia Ivakina} \\ Doctoral student, Graduate School of Management, \\ St. Petersburg State University \\ 3 Volkhovsky Ln, St. Petersburg, Russia \\ E-mail: anastasiyaivakina@gmail.com
}

$\mathrm{PhD}$, Associate professor, Operations Management Department, Graduate School of Management,

\begin{abstract}
This article is devoted to working capital management and its optimization on an inter-organizational level when supply chain members operate collaboratively. We aim to develop and validate a model of collaborative approach to working capital management in supply chains for cases of constrained liquidity and imposed return requirements using supply chain finance (factoring, reverse factoring and inventory financing). As such, we suggest a tool of working capital optimization using financial terms and cash flows verified on Russian supply chain data. Mathematical modeling is suggested as a method to modify an existing working capital management model on the grounds of collaborative financial cost minimization under industry specific liquidity constraints. These liquidity constraints are constructed in such a way as to eliminate possible violations from companies, because their violation will lead to the inverse relation between liquidity and rate of return. The results of the optimization provide recommended values for cash conversion cycle elements days of inventories, days of accounts payable, days of accounts receivable - that guarantee the coordinating effect of collaborative working capital management. Calculation, further optimization and monitoring of cash conversion cycle values sustain effective working capital management on an inter-organizational level while meeting the liquidity and return levels for each company in a chain. The suggested model can be implemented for a day-to-day decision making process by companies oriented to stay competitive in the long run. Besides, the results obtained show the potential for further coordination among the key members of the supply chain in terms of aligning financial, product, and information flows. Despite the fact that the model provides a static solution to the problem of collaborative working capital management, it has potential for the further development of a dynamic algorithm. Future research should seek to investigate the possible imputation options for gained costs reduction values on the grounds of cooperative games with a coalition structure.
\end{abstract}

Keywords: supply chain management, supply chain finance; working capital; working capital management; cash conversion cycle, collaborative cash conversion cycle

JEL: C02, C61, G31, G32, M41

\footnotetext{
${ }^{1}$ The research is financially supported by the Russian Foundation for Basic Research under grant №16-01-0085/A and №17-07-00371/A.
} 


\section{Introduction}

In the field of supply chain management (SCM), collaboration between business partners (basic raw materials and components suppliers, manufacturers, distributors, transporters, retailers, banks and financial institutions, etc.) linked through the flows of goods, information and finance is a core concept. Research on supply chains (SCs) has mainly focused on inventory cost, transportation cost and cost related to goods procurement. However, there has been very little research work focusing on the flow of money [1]. It has been stated that, in terms of a swiftly changing business environment, [2] "for an effective supply chain system, the management of upstream flow of money is as important as the management of downstream flow of goods." From this perspective, working capital management (WCM) as an essential element of financial supply chain management (FSCM) has gained a lot of attention [3-8] due to the fact that it is a way to accelerate the cycle time of working capital (WC) and increase the profitability of the company in response to financial volatility in the business environment (e.g. the enacted Basel II), restraining external financing from banks. Consequently, the demand for capital from within the SC, e.g. from companies directly involved in supply chain finance (SCF) schemes or acting as financial service providers (FSPs) has increased [9-16]. For this reason, the importance of effective WCM has raised dramatically, especially for SCs from emerging markets, which faced difficulties with access to capital, limited financial infrastructure and legal, regulatory and accounting uncertainties in the first place.

Apart from that, the focus of the study on emerging markets is also prompted by the fact that SCs stretch across the globe with a diverse range of suppliers in emerging markets, and the failure of a supplier can impact most severely the whole production process, threatening the viability and continuity of an entire SC. So, WCM is increasingly transcending boundaries of mature markets and has the potential for economic stabilization, however most emerging market companies have not yet fully realized its benefits.

Likewise, the coordinating mechanisms of WCM and SCF in SCs have received little attention because the role of financial coordinators (FSPs, banks, FinTech companies and other financial intermediaries) as core participants in facilitating and enabling SCF has only recently been identified in academic literature [12-14; 17].

Additionally, the research is motivated by the call for a more holistic approach to SCM on the grounds of merging financial and operational SC measures, since the existing literature either considers them separately or does not give insights on financial flows [18; 19].

We address these gaps and aim to develop a WCM model providing optimal levels of working capital to every business partner through collaborative actions of capital reallocation along the SC. As such, the main aim of the research is to suggest a tool for working capital optimization under the constraints of a profitability-liquidity tradeoff verified on Russian collaborative SC data. The paper begins with a review of SC collaboration and WCM literature leading to the research question:

RQ: How to improve the working capital position of each $S C$ business partner by improving the integral performance of the SC at the same time?

The selected methodology aiming at responding to the research question represents the upgrading of the approach proposed by [10]. In response to the RQ, a model is developed; this is followed by numerical analysis and discussion of the findings. The paper closes with a conclusion, identifying further research directions.

\section{Literature review}

\section{Supply chain collaboration}

From a strategic management point of view, one of the most challenging collaboration perspectives is to extend the concept from collaboration within an organization to the level between organizations, since they do not exist in isolation [20-22]. Any organization, whether a large corporation, public body, or a small business, aims to meet the needs of its various customers and stakeholders, will need resources to do this, and will acquire many of its materials, equipment, facilities and supplies from other organizations. The performance of an organization is thus influenced by the actions of the organizations that make up the supply chain [23-26]. Therefore, focus has moved from competition between firms at the same level in the production process to competition between supply chains, from raw materials to end customers $[27 ; 28]$. A company's ability to create trust-based and long-term business relationships with customers, suppliers, and other strategic partners becomes a crucial competitive parameter. Though it is accepted that external relationships in SCM are strategically important, still many questions concerning operations integration with suppliers and customers in SC remain unanswered [23; 29-32].

SC collaboration is especially important to manage external relationships with suppliers and customers [33]. The empirical results indicate that SC collaboration considerably improves the collaborative advantage [34], which in turn, has a significant positive effect on firms' financial performance (in particular, the mediator role of collaborative advantage is stronger for small firms than medium and large firms [35]. Furthermore, a lack of collaboration may result in poor performance of the whole SC [36], with such consequences as: inaccurate forecasts, low capacity utilization, excessive inventory, inadequate customer service, inventory turns, inventory costs, time to market, order fulfillment response, quality, customer focus and customer satisfaction [37-39], not to mention the perspective representing the "dark side" of inter-firm collaboration, which characterizes many buyer-supplier relationships [40-42]. 
It has been well documented by operations management scholars and practitioners, that communication between business partners is the essence of organizational life [40; 43]. However, in empirical studies, researchers have typically considered inter-organizational communication as a part of a broader construct, or have examined the extent to which the use of selected communication strategies by buyer firms enhances supplier firm operational performance. Furthermore, the majority of research focuses on the economic value for buyers or for suppliers; few studies investigate how the strategic orientations of buyers and suppliers affect the relative relationship performance for the individual dyad members $[44 ; 45]$. That being said, traditional perspectives that suppliers and buyers act as independent economic agents are being replaced with the understanding that these exchange partners are co-producers of value, and thus their performances are interlinked [17; 46-50]. Cachon and Lariviere (2005) published a paper [51] analyzing the role of revenue sharing contracts in coordinating a supply chain. The idea is straightforward: organizations are self-serving entities maximizing individual profits, but sometimes this might result in a sub-optimal overall performance. However, a focal company can contractually coordinate the actions of other players in the supply chain in order to achieve optimal profit.

With this in mind, in the next paragraph we will mainly leave out of consideration a large body of working capital and cash management literature which provides solutions aimed at improving working capital position for a single company, and which thus neglects the inter-organizational perspective of the issue [e.g. 3; 4; 52-55]. Instead, we will focus on the recent papers outlining approaches to working capital management in the context of collaboration between business partners in a supply chain.

\section{Working capital management}

Finance literature captures financial flows as working capital (WC). There are two main perspectives regarding working capital. The first one defines it as the ability of the company to cover its short-term debt with current assets. In [56] the author defines the concept of this working capital perspective and describes it with the equation (1):

Working capital $=$ Current assets - Current liabilities. (1)

According to [56], current assets consist of cash, total inventory, accounts receivable, securities and cash equivalents. On the other side, current liabilities refer to accounts payable, accruals, notes payable and short-term debt. A positive result of working capital means that the amount of cash the company will receive in the next 12 months is bigger than what the company needs to cover its liabilities. A negative result of working capital means that the company will not be able to cover its short-term debt (1).

Another perspective on working capital which is widely utilised in most of the studies dedicated to operating working capital involves considering the total level of inventory, accounts receivable $(A / R)$ and accounts payable $(\mathrm{A} / \mathrm{P})$. According to [57], the equation is following:
Working capital $=$ Inventories $+A R-A P$.

The study [58] included accrued expenses (A/E) in (2) as a separate component into the working capital cycle (usually is a part of A/P). The authors $[57,58]$ state that the working capital cycle describes the main parts of the company's performance associated with financial flows.

The operational approach to evaluate working capital is a time-based measure of a cash conversion cycle (CCC), introduced by the authors at [59] for measuring and controlling the effectiveness of working capital management on the basis of relative ratios. Other authors $[3 ; 60 ; 61]$ have agreed that CCC is an adequate proxy for working capital management. The CCC (3) presents the length (in days) of time in which a firm has funds tied up in working capital, starting from the payment of purchases to the supplier and ending when remittance of sales is received from the customers. In other words, the CCC is a collection of three sub-cycles: the cycle time of inventories $(D I O)$ plus the cycle time of accounts receivable (DRO) minus the cycle time of accounts payable (DPO).

$$
C C C=D I O+D R O-D P O .
$$

CCC as working capital can be either negative or positive. Negative CCC means that the company has a low amount of inventory and the company receives money from its customers before it has to pay its A/R. In other words, in a negative CCC scenario, a company receives its $\mathrm{A} / \mathrm{R}$ before it should pay A/P. A large number of researchers believe that the lower the CCC is, the better a company can manage its cycles efficiently, although a CCC which is too low can cause problems with each individual component of the CCC [62-64].

Considering the problem of identifying the CCC optimal value, there arises the issue of achieving target rates of return and, at the same time, maintaining the necessary level of liquidity [65-67]. In recent years the number of studies devoted to this issue has boomed, though the results are controversial and incomparable due to a number of reasons with research method selection among them (case studies [46; 68]; regression analysis of annual financial statements $[4 ; 8 ; 18 ; 63]$; optimization modeling [10; 69-71].

As far as it goes, there is mixed evidence concerning the inverse relation between CCC and its components and profitability $[3 ; 4 ; 60 ; 68 ; 72]$ as well as direct relations between CCC and its components and liquidity [73]. However, the general conviction on this issue is the following: an increase of CCC will reduce risk and profitability on the one hand, and will improve liquidity on the other.

Clearly, each company pursuing its target levels of liquidity and profitability implements a set of working capital policies [18] usually referred to as conservative, moderate or aggressive. The aggressive working capital policy implies estimation of current assets at the lowest possible level resulting in lower working capital requirements and higher risks. Conservative policy, on the other hand, is aimed at avoiding the maximum possible risks and guarantees the 
smooth operation of the company, though the higher level of current assets leads to lower profitability. Moderate policy is assumed to be a tradeoff between the aggressive and conservative policies providing relatively balanced levels of profitability and liquidity.

In line with this classification, the contribution [66] suggests the theoretical typology of various financial working capital management strategies, focusing on maximization or minimization of CCC components aiming to improve the financial working capital. Authors claim these strategies are to be pursued during the economic downturn, which make them possible to apply for companies from emerging markets. This is appropriate due to the fact that these companies faced difficulties with access to capital, limited financial infrastructure and legal, regulatory and accounting uncertainties well before spreading volatility in the business environment as well as the enacted Basel II restrained access to financing from banks and increased demand for capital from within the SC $[10 ; 12 ; 14 ; 54 ; 66]$. For these reasons, the practitioners' interest in effective WCM on inter-organizational level has increased dramatically, which resulted in a wave of publications $[6 ; 7 ; 14$; $15 ; 19 ; 57 ; 58 ; 74-77]$.

The primary motivation behind much of this research (besides the previously-mentioned post-crisis challenges) is the idea that finance research on WCM has been focusing on company profitability instead of supply chain contribution, and consequently companies are seeking to optimize their individual performance. However, none of its elements can be truly managed by a company individually, but only in collaboration with business partners. It is important to note that individual financial performance optimization is to be considered in terms of a more holistic approach, taking into account each participant's interests as well as the ability to collaborate, or, in other words, taking into account the supply chain orientation of a company.
With this in mind, an initial assumption for further optimization is, following [51], collaboration of supply chain partners already motivated to maximize total profit of the chain. Alternatively, this motivation can be reformulated in terms of total financial costs minimization, and specifically financial costs associated with WCM.

\section{Collaborative working capital optimization model}

\section{Base model}

Building on earlier research, this study attempts to address the gaps from the extant body of WCM literature by suggesting an upgrading of the collaborative cash conversion cycle (CCCC) model originally introduced by [10]. Authors denote CCCC as a sum of the cash conversion cycles of all exchange partners. They show, by means of optimization modeling, that a reduction of the cash conversion cycle for a single company in a chain (possibly on the expense of suppliers or customers) does not add value to other SC partners. While resulting in short-term balance-sheet improvements, it eventually triggers a higher risk supplier base and, consequently, an increased total cost of running business in long-term. The study provides clear argumentation as to, why the true optimization approach to the problem of finding optimal cash conversion cycle length lies in the area of collaborative actions of all affiliated members.

As such, for the purposes of our study we consider a collaborative wholesaler's three-stage SC with $N$ suppliers and $M$ retailers at the first and third stages respectively (see Fig. 1).

To capture the financial costs associated with each SC stage, we consider the formula (5) introduced by [78]. Consequently, the objective function of our model is collaborative financial costs $(C F C)$, which sums financial costs of all supply chain participants (4):

$$
\begin{aligned}
& C F C=\sum_{l=1}^{3} \sum_{k=1}^{K_{l}} F C_{l}^{k}, \\
& F C_{l}^{k}\left(D I O_{l}^{k}, D R O_{l}^{k}, D P O_{l}^{k}, I N V_{l}^{k}, A R_{l}^{k}, A P_{l}^{k}\right)= \\
& =I N V_{l}^{k}\left[\left(1+c_{l}^{k}\right)^{\frac{D I O_{l}^{k}}{365}}-1\right]+A R_{l}^{k}\left[\left(1+c_{l}^{k}\right)^{\frac{D R O_{l}^{k}}{365}}-1\right]-A P_{l}^{k}\left[\left(1+c_{l}^{k}\right)^{\frac{D P O_{l}^{k}}{365}}-1\right]
\end{aligned}
$$

As mentioned before, our approach to solving the problem of working capital optimization is grounded within the supply chain collaboration stream of research. We imply that minimization of total financial costs associated with certain supply stages is of common interest for all SC members, and they are financially motivated toward collaborative actions. The rationale behind such a collaboration (6) is that the financial costs of each participant operating in collaboration $\left(F C_{l}^{k}\right)$ do not exceed their values while operating independently $\left(F C_{l}^{0 k}\right)$ :

$$
F C_{l}^{k} \leq F C_{l}^{0 k}
$$


Figure 1. Collaborative supply chain

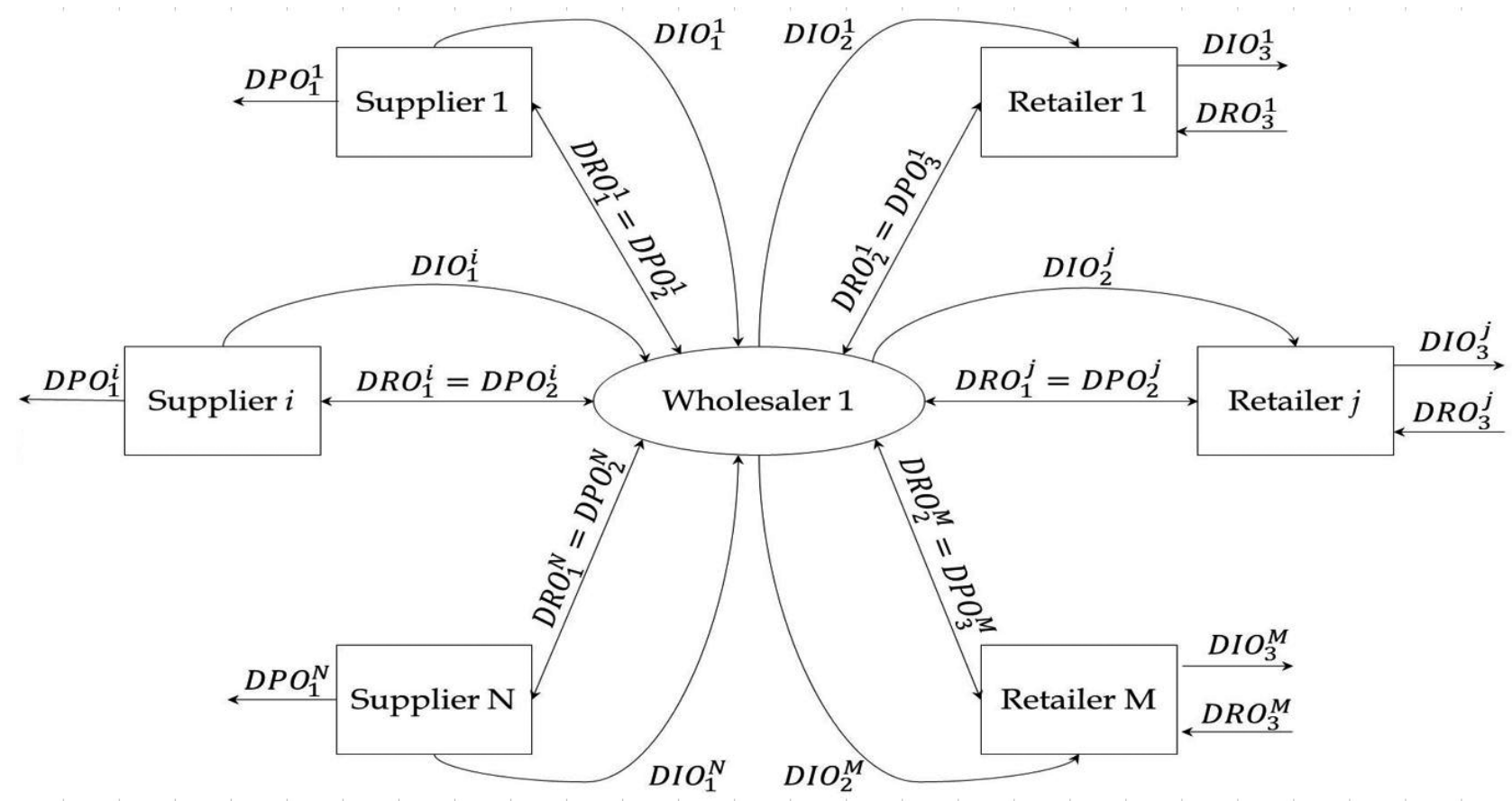

For this SC structure, and following [10], we define collaborative cash conversion cycle (CCCC, 7) as the sum of the CCCs of all participants (8):

$$
C C C C=\sum_{l=1}^{3} \sum_{k=1}^{K_{l}} C C C_{l}^{k}
$$

$$
C C C_{l}^{k}=D I O_{l}^{k}+D R O_{l}^{k}-D P O_{l}^{k} .
$$

Concerning the liquidity-return trade-off, we suppose companies in a focal supply chain are pursuing a moderate approach to working capital management. Our aim is to ensure that companies' current ratios are higher than the industry average rate of return and at the same time is below the value at which the relation between liquidity and rate of return becomes inverted $[63 ; 65]$. Hence, we denote individual cash conversion cycles $\left(C C C_{l}^{k}\right)$ to confine to a recommended industry specific stability interval $C C C_{\text {low }}, C C C^{u p}$ providing favorable balance between return and liquidity (9):

$$
C C C_{\text {low }} \leq C C C_{l}^{k} \leq C C C^{u p} \text {. }
$$

Introducing constraints on CCCC components (10 and 11), we aim to incorporate the inward-oriented approach to optimization stemming from two assumptions [10]. First, we assume the nature of relations between the exchange partners in the supply chain (Fig. 1). We are fully aware of an underlying simplification of the focal supply chain structure, as real-life supply chains (or rather multidimensional networks) show a greater degree of complexity. However, we denote internal payment periods among SC players do not have impact on CCCC:

$$
D R O_{l}^{k}=D P O_{l+1}^{k} \text {, where } l=\overline{1,2}, k=\overline{1, K_{l}} \text {. }
$$

Secondly, we assume that companies pursuing inward-oriented optimization will restrain from exploiting the capacities of contractors outside the specified supply chain perimeter (11). As such, we denote values of days of payables outstanding at the suppliers stage $\left(D P O_{1}^{k}\right)$ and days of receivables outstanding at the retailers stage ( $D R O_{3}^{k}$ ) after optimization should equal their values before optimization $\left(D P O_{1}^{0 k}\right.$ and $D R O_{3}^{0 k}$ consequently):

$$
\begin{aligned}
& D P O_{1}^{k}=D P O_{1}^{0 k}, k=(1, N), \\
& D R O_{3}^{k}=D R O_{3}^{0 k}, k=(1, M) .
\end{aligned}
$$

Although the literature suggests that the shorter the inventory holding period is, the better the liquidity position of the company will be, we aim to limit the dramatic reductions in inventory as a result of optimization procedures possibly leading to decreased customer service due to stock-outs and an increased bullwhip effect [18]. Hence we assume that each company in a chain pursues individual inventory management policies with specific stock level requirements (12):

$$
D I O_{l}^{k} \geq D I O_{l o w} \text {. }
$$

Furthermore, we suppose CCCC components to be nonnegative and continuous (13):

$$
D I O_{l}^{k}, D R O_{l}^{k}, D P O_{l}^{k} \geq 0 \text {. }
$$

Table 1 provides the notations of our model. 
Table 1. Model parameters

\section{Indices}

Stage; $l=\overline{1,3}(1$ - supplier stage, 2 - wholesaler stage, 3 - retailer stage)

$k \quad$ Company; $k=\overline{1, K_{l}}, K_{l}=\left\{\begin{array}{c}N, l=1, \\ 1, l=2, \\ M, l=3 .\end{array}\right.$

\section{Objective function}

CFC Collaborative financial costs

\section{Parameters}

\begin{tabular}{|c|c|}
\hline$I N V_{l}^{k}$ & Level of inventory of company $k$ at stage $l$ at year-end $l$ \\
\hline$A R_{l}^{k}$ & Level of accounts receivable of company $k$ at stage $l$ at year-end $l$. \\
\hline$A P_{l}^{k}$ & Level of accounts payable of company $k$ at stage $l$ at year-end $l$ \\
\hline$W C_{l}^{k}$ & Working capital position of company $k$ at stage $l$ \\
\hline$C O G S_{l}^{k}$ & Value of annual cost of goods sold of company $k$ at stage $l$ \\
\hline$R_{l}^{k}$ & Value of annual revenue of company $k$ at stage $l$ \\
\hline$c_{l}^{k}$ & Annual cost of capital for company $k$ at stage $l$ \\
\hline$C C C_{l}^{k}$ & Cash conversion cycle of company $k$ at stage $l$ \\
\hline$C C C_{\text {low }}, C C C^{u p}$ & Target stability levels of cash conversion cycle of company $k$ at stage $l$ \\
\hline$F C_{l}^{k}$ & Financial costs of company $k$ at stage $l$ \\
\hline$F C_{l}^{0 k}$ & Financial costs of company $k$ at stage $l$ at year-beginning \\
\hline$D I O_{l o w}$ & Minimal stock level \\
\hline
\end{tabular}

Variables

$D I O_{l}^{k} \quad$ Days of inventory outstanding for company $k$ at stage $l$

$D R O_{l}^{k} \quad$ Days of accounts receivable outstanding for company $k$ at stage $l$

$D P O_{l}^{k} \quad$ Days of accounts payable outstanding for company $k$ at stage $l$

We construct the optimization model as follows: to minimize collaborative financial costs (4) under constraints (6), (9) - (13). Therefore, we find the optimal cycle times of inventories $\left(D I O_{l}^{k}\right)$, accounts receivable $\left(D R O_{l}^{k}\right)$ and accounts payable ( $D P O_{l}^{k}$ ) minimizing the overall financial costs of a supply chain under specific liquidity, profitability, and inventory constraints for its members over a planning period of one year.
The objective function and constraints are separable functions; hence for solving this nonlinear separable programming problem we employ a general algorithm of gradient method [79]. As the developed model represents a nonlinear programming problem, it is impossible to receive its solution in closed form and the next section provides numerical analysis of the model applied to a case of an ICT supply chain from Russia. 
Figure 2. The financial flows of a focal SC

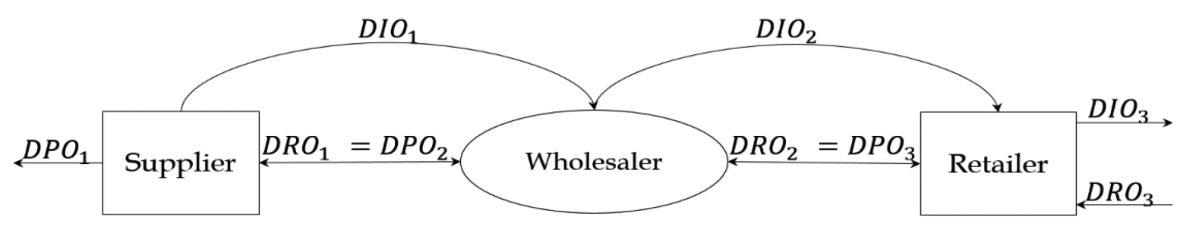

\section{Numerical analysis}

In this section, we present our findings of optimization modeling by an illustrative numerical example. The choice of a SC operating in the information and communication technology (ICT) industry for numerical analysis is motivated by the fact that it is characterized by a highly integrated business environment and fast technology development [57]. It is service-oriented, and has a large variety of end products and customers. Worthy of note is that even though individual companies in the ICT industry have been used in many case studies, and the SCs of single products have been examined, the ICT chains at the industry level have been rarely addressed [80].

We consider a chain consisting of a single supplier, wholesaler and retailer (Fig. 2).

The focal company of the chain (the 'Wholesaler') is a Russian public telecommunication services provider holding licenses for local, long-distance and mobile telephone services, data, TV and value-added solutions to residential, corporate and governmental subscribers and third-party operators across all regions of the Russian Federation, Europe and Asia. According to the Wholesaler's strategy, it aims to move from fixed line operator to integrated digital service provider based on technological, service and efficiency enhancement aspects. For the latter goal, optimization of capital expenditure with focus on return on investment is one of the main directions considered. As such, the company is applying operational efficiency upgrading programs, procurement optimization being one of them. Thereby, the Wholesaler orients itself towards transparency, freedom from discrimination and unwarranted competition-blocking for all its potential suppliers, including small and medium enterprises, pursuing procurement on electronic communications networks.

The 'Supplier' (Fig. 2) is one of the large domestic system integrators, involved in the Wholesaler's procurement process5, operating in Russia, the CIS countries and Europe. The Supplier's business profile is oriented toward realization of large scale, socially significant projects on the implementation, development and outsourcing of telecom infrastructure, information security systems, energy and engineering systems, and industrial application platforms. The 'Retailer' in the considered SC (Fig. 2) is a mobile phone company integrated with the Wholesaler, providing a wide range of services, including a high-speed mobile internet service, across the Russian Federation. The Retailer's business is based on a unique and efficient model: high-quality services at low costs. Cost control and focus on highly demanded products help the company outpace the growth of other mobile operators showing considerable growth rates of the subscriber base. However, the Retailer's financial performance is weak due to extremely high leverage resulting from recent telecom network construction.

The model parameters we consider are based on data (Tab. 2) retrieved from the Wholesaler's Annual Report and interviews with the Supplier's and the Retailer's financial managers.

Table 2. Year-beginning data (before optimization)

\begin{tabular}{|c|c|c|c|c|}
\hline & Supplier & Wholesaler & Retailer & Total (SC) \\
\hline$I N V_{l}^{0}$ & $1,342.0$ & $11,593.0$ & 972.0 & $13,907.0$ \\
\hline$A R_{l}^{0}$ & $1,374.0$ & 458.1 & 119.0 & $1,951.1$ \\
\hline$A P_{l}^{0}$ & 901.0 & $4,256.1$ & 85.0 & $5,242.1$ \\
\hline$W C_{l}^{0}$ & $1,815.0$ & $7,795.0$ & $1,006.0$ & $10,616.0$ \\
\hline$C O G S_{l}^{0}$ & $6,345.0$ & $22,981.0$ & $5,528.0$ & $\mathrm{X}$ \\
\hline$R_{l}^{0}$ & $7,419.0$ & $29,792.0$ & $6,588.0$ & $\mathrm{X}$ \\
\hline$c_{l}^{0}$ & $8.2 \%$ & $4.7 \%$ & $3.4 \%$ & $\mathrm{X}$ \\
\hline$D I O_{l}^{0}$ & 77.2 & 184.1 & 64.2 & $\mathrm{X}$ \\
\hline$D R O_{l}^{0}$ & 67.6 & 5.6 & 6.6 & $\mathrm{X}$ \\
\hline$D P O_{l}^{0}$ & 51.8 & 67.6 & 5.6 & $\mathrm{X}$ \\
\hline$C C C_{l}^{0}$ & 93.0 & 122.1 & 65.2 & 280.3 \\
\hline$F C_{l}^{0}$ & 32.5 & 237.7 & 5.7 & 276.0 \\
\hline
\end{tabular}

We investigate two modeling scenarios. In the scenario of initial performance within the CCC stability range, we assume the members of the supply chain each have achieved the target levels of CCC providing suitable balance between return and liquidity in a prior time period. In the scenario of initial performance outside the CCC stability range, the members of the supply chain each have the target CCC values to be achieved in current planning period. However, we assume that in both scenarios each supply chain member has sufficient motivation to proceed to working capital optimization on the grounds of total financial costs minimization. Our results demonstrate 
significant benefits of working capital re-allocation on the grounds of financial costs minimization.

\section{Initial performance outside the CCC stability range}

\section{Without changing the inventories levels}

The base model implies the optimization of collaborative CCC components for supply chain members directly inside the specified SC perimeter. For this reason, we are testing the consequences of not changing the initial levels of inventories in the scenario of companies performing outside the CCC stability range. This condition and outlined model parameters provided us with a result of missing feasible solution, meaning that for this case optimization based solely on changing payment terms for supply chain partners is impossible.

However, optimization is possible (Tab. 3a and Tab. 3b) if the range of CCC providing acceptable return-liquidity trade-off is broadened from $(-16.18,61.50)$ as recommended by [65] for companies from ICT industry to $(-16.18,116.53)$. The results also illustrate inadequate results, as the obtained marginal reduction in working capital requirements demands harsh changes to payment policies at the expense of the Retailer. It is highly questionable that, being the weaker member of the chain, he will tolerate this approach to repayment.

Table 3a. Year-end data (after optimization)

\begin{tabular}{|c|c|c|c|c|}
\hline$L$ & Supplier & Wholesaler & Retailer & Total (SC) \\
\hline$I N V_{l}^{k}$ & $1,342.0$ & $11,593.0$ & 972.0 & $13,907.0$ \\
\hline$A R_{l}^{k}$ & $1,374.0$ & 0.0 & 119.0 & $1,493.0$ \\
\hline$A P_{l}^{k}$ & 901.0 & $4,256.1$ & 0.0 & $5,157.1$ \\
\hline$W C_{l}^{k}$ & $1,815.0$ & $7,336.9$ & $1,091.0$ & $10,242.9$ \\
\hline$C O G S_{l}^{k}$ & $6,345.0$ & $22,981.0$ & $5,528.0$ & $\mathrm{X}$ \\
\hline$R_{l}^{k}$ & $7,419.0$ & $29,792.0$ & $6,588.0$ & $\mathrm{X}$ \\
\hline$c_{l}^{k}$ & $8.2 \%$ & $4.7 \%$ & $3.4 \%$ & $\mathrm{X}$ \\
\hline$D I O_{l}^{k}$ & 77.2 & 184.1 & 64.2 & X \\
\hline$D R O_{l}^{k}$ & 67.6 & 0.0 & 6.6 & $\mathrm{X}$ \\
\hline$D P O_{l}^{k}$ & 51.8 & 67.6 & 0.0 & $\mathrm{X}$ \\
\hline$C C C_{l}^{k}$ & 93.0 & 116.5 & 70.8 & 280.3 \\
\hline$F C_{l}^{k}$ & 32.5 & 237.4 & 5.8 & 275.7 \\
\hline
\end{tabular}

Table 3b. Comparative change

\begin{tabular}{|c|c|c|c|c|}
\hline$l$ & Supplier & Wholesaler & Retailer & Total (SC) \\
\hline$I N V_{l}^{k}$ & $0 \%$ & $0 \%$ & $0 \%$ & $0 \%$ \\
\hline$A R_{l}^{k}$ & $0 \%$ & $-100 \%$ & $0 \%$ & $-23 \%$ \\
\hline$A P_{l}^{k}$ & $0 \%$ & $0 \%$ & $-100 \%$ & $-2 \%$ \\
\hline$W C_{l}^{k}$ & $0 \%$ & $-6 \%$ & $8 \%$ & $-4 \%$ \\
\hline$D I O_{l}^{k}$ & $0 \%$ & $0 \%$ & $0 \%$ & $\mathrm{X}$ \\
\hline$D R O_{l}^{k}$ & $0 \%$ & $-100 \%$ & $0 \%$ & $\mathrm{X}$ \\
\hline$D P O_{l}^{k}$ & $0 \%$ & $0 \%$ & $-100 \%$ & $\mathrm{X}$ \\
\hline$C C C_{l}^{k}$ & $0 \%$ & $-5 \%$ & $9 \%$ & $0 \%$ \\
\hline$F C_{l}^{k}$ & $0 \%$ & $0 \%$ & $1 \%$ & $0 \%$ \\
\hline
\end{tabular}

\section{Changing the inventories levels}

Building on earlier results of modeling, we observed the requirement for the collaborative inventories management of all SC partners as well as payment terms in order to achieve satisfying and practically reasonable working capital re-allocation along the supply chain. However, the result obtained (Tab. 4a and Tab. 4b) is hardly practically achievable even through usage of all the spectrum of SCF solutions and instruments. The optimization here requires reallocation of roughly $80 \%$ of the inventories to the $3 \mathrm{PL}$ provider facilitating inventories financing instruments. Moreover, it demands a delay in payment to customers downstream. Technically, this will lead to a significant improvement both in overall working capital position as well as in total financial costs decline, though the solution does not take into the account costs of such an inventory financing scheme and the possible outcomes of the payment re-scheduling.

Table 4a. Year-end data (after optimization)

\begin{tabular}{|c|c|c|c|c|}
\hline$l$ & Supplier & Wholesaler & Retailer & Total (SC) \\
\hline$I N V_{l}^{k}$ & 0.1 & $2,705.5$ & 203.4 & $2,908.9$ \\
\hline$A R_{l}^{k}$ & $1,938.1$ & $2,954.7$ & 119.0 & $5,011.8$ \\
\hline$A P_{l}^{k}$ & 901.0 & $6,003.4$ & 548.3 & $7,452.7$ \\
\hline$W C_{l}^{k}$ & $1,037.2$ & -343.2 & -225.9 & 468.1 \\
\hline
\end{tabular}




\begin{tabular}{|c|c|c|c|c|}
\hline$l$ & Supplier & Wholesaler & Retailer & Total (SC) \\
\hline$C O G S_{l}^{k}$ & $6,345.0$ & $22,981.0$ & $5,528.0$ & $\mathrm{X}$ \\
\hline$R_{l}^{k}$ & $7,419.0$ & $29,792.0$ & $6,588.0$ & $\mathrm{X}$ \\
\hline$c_{l}^{k}$ & $8.2 \%$ & $4.7 \%$ & $3.4 \%$ & $\mathrm{X}$ \\
\hline$D I O_{l}^{k}$ & 0.0 & 43.0 & 13.4 & $\mathrm{X}$ \\
\hline$D R O_{l}^{k}$ & 95.4 & 36.2 & 6.6 & $\mathrm{X}$ \\
\hline$D P O_{l}^{k}$ & 51.8 & 95.4 & 36.2 & $\mathrm{X}$ \\
\hline$C C C_{l}^{k}$ & 43.5 & -16.2 & -16.2 & 11.2 \\
\hline$F C_{l}^{k}$ & 30.1 & -44.7 & -1.5 & -16.1 \\
\hline
\end{tabular}

The illustrative examples lead us to the conclusion that working capital optimization is complicated for the case of relatively high stock levels.

Table 4b. Comparative change

\begin{tabular}{|c|c|c|c|c|}
\hline$l$ & Supplier & Wholesaler & Retailer & Total (SC) \\
\hline$I N V_{l}^{k}$ & $-100 \%$ & $-77 \%$ & $-79 \%$ & $-79 \%$ \\
\hline$A R_{l}^{k}$ & $41 \%$ & $545 \%$ & $0 \%$ & $157 \%$ \\
\hline$A P_{l}^{k}$ & $0 \%$ & $41 \%$ & $545 \%$ & $42 \%$ \\
\hline$W C_{l}^{k}$ & $-43 \%$ & $-104 \%$ & $-122 \%$ & $-96 \%$ \\
\hline$D I O_{l}^{k}$ & $-100 \%$ & $-77 \%$ & $-79 \%$ & $\mathrm{X}$ \\
\hline$D R O_{l}^{k}$ & $41 \%$ & $545 \%$ & $0 \%$ & $\mathrm{X}$ \\
\hline$D P O_{l}^{k}$ & $0 \%$ & $41 \%$ & $545 \%$ & $\mathrm{X}$ \\
\hline$C C C_{l}^{k}$ & $-53 \%$ & $-113 \%$ & $-125 \%$ & $-96 \%$ \\
\hline$F C_{l}^{k}$ & $-7 \%$ & $-119 \%$ & $-126 \%$ & $-106 \%$ \\
\hline
\end{tabular}

However, the scheme of proportional reduction of inventories for at least one business partner in conjunction with usage of SCF instruments has a potential of providing optimal solutions to the problem of working capital re-allocation (Tab. 5a and Tab. 5b).
Table 5a. Year-end data (after optimization)

\begin{tabular}{|c|c|c|c|c|}
\hline & Supplier & Wholesaler & Retailer & Total (SC) \\
\hline$I N V_{l}^{k}$ & 878.8 & $7,591.7$ & 636.5 & $9,107.0$ \\
\hline$A R_{l}^{k}$ & $1,276.0$ & 0.0 & 119.0 & $1,395.0$ \\
\hline$A P_{l}^{k}$ & 901.0 & $3,952.5$ & 0.0 & $4,853.5$ \\
\hline$W C_{l}^{k}$ & $1,253.8$ & $3,639.2$ & 755.5 & $5,648.5$ \\
\hline$C O G S_{l}^{k}$ & $6,345.0$ & $22,981.0$ & $5,528.0$ & $\mathrm{X}$ \\
\hline$R_{l}^{k}$ & $7,419.0$ & $29,792.0$ & $6,588.0$ & $\mathrm{X}$ \\
\hline$c_{l}^{k}$ & $8.2 \%$ & $4.7 \%$ & $3.4 \%$ & $\mathrm{X}$ \\
\hline$D I O_{l}^{k}$ & 50.6 & 120.6 & 42.0 & $\mathrm{X}$ \\
\hline$D R O_{l}^{k}$ & 62.8 & 0.0 & 6.6 & $\mathrm{X}$ \\
\hline$D P O_{l}^{k}$ & 51.8 & 62.8 & 0.0 & $\mathrm{X}$ \\
\hline$C C C_{l}^{k}$ & 61.5 & 57.8 & 48.6 & 167.9 \\
\hline$F C_{l}^{k}$ & 16.9 & 85.4 & 2.5 & 104.8 \\
\hline
\end{tabular}

Table 5b. Comparative change

\begin{tabular}{|c|c|c|c|c|}
\hline$l$ & Supplier & Wholesaler & Retailer & Total (SC) \\
\hline$I N V_{l}^{k}$ & $-35 \%$ & $-35 \%$ & $-35 \%$ & $-35 \%$ \\
\hline$A R_{l}^{k}$ & $-7 \%$ & $-100 \%$ & $0 \%$ & $-29 \%$ \\
\hline$A P_{l}^{k}$ & $0 \%$ & $-7 \%$ & $-100 \%$ & $-7 \%$ \\
\hline$W C_{l}^{k}$ & $-31 \%$ & $-53 \%$ & $-25 \%$ & $-47 \%$ \\
\hline$D I O_{l}^{k}$ & $-35 \%$ & $-35 \%$ & $-35 \%$ & $\mathrm{X}$ \\
\hline$D R O_{l}^{k}$ & $-7 \%$ & $-100 \%$ & $0 \%$ & $\mathrm{X}$ \\
\hline$D P O_{l}^{k}$ & $0 \%$ & $-7 \%$ & $-100 \%$ & $\mathrm{X}$ \\
\hline$C C C_{l}^{k}$ & $-34 \%$ & $-53 \%$ & $-25 \%$ & $-40 \%$ \\
\hline$F C_{l}^{k}$ & $-48 \%$ & $-64 \%$ & $-56 \%$ & $-62 \%$ \\
\hline
\end{tabular}

For example, proportional reduction of inventories cycles for all members of the focal chain by at least $35 \%$ and the speed-up of the DRO cycle for suppler and distributor by $7.13 \%$ provides a decrease of total financial costs by 
$62 \%$. In other words, for the case of high initial levels of inventories one of the members of the chain is to take the initiative of managing and coordinating the inventories along the whole chain, keeping them at lowest cost possible. At the same time, managing the inventories along the chain implies the task of synchronization of individual inventory management and supply chain strategy.

\section{Initial performance within the CCC stability range}

Assuming the supply chain partners have already reached the levels (Tab. 6a) whereby each company's current ratio is higher than the industry average rate of return and at the same time is below the value at which the relation between liquidity and rate of return becomes inverse [65], we found out that working capital reallocation through the use of SCF instruments can entail a decrease in the total financial costs of the whole supply chain.

Table 6a. Case of year-beginning data within the CCC stability range (before optimization).

\begin{tabular}{|c|c|c|c|c|}
\hline$l$ & Supplier & Wholesaler & Retailer & Total (SC) \\
\hline$I N V_{l}^{0}$ & 869.2 & $5,666.5$ & 757.3 & $7,293.0$ \\
\hline$A R_{l}^{0}$ & $1,219.6$ & 816.2 & 119.0 & $2,154.8$ \\
\hline$A P_{l}^{0}$ & 901.0 & $3,777.7$ & 151.5 & $4,830.2$ \\
\hline$W C_{l}^{0}$ & $1,187.7$ & $2,705.1$ & 724.8 & $4,617.6$ \\
\hline$C O G S_{l}^{0}$ & $6,345.0$ & $22,981.0$ & $5,528.0$ & $\mathrm{X}$ \\
\hline$R_{l}^{0}$ & $7,419.0$ & $29,792.0$ & $6,588.0$ & $\mathrm{X}$ \\
\hline$c_{l}^{0}$ & $8.2 \%$ & $4.7 \%$ & $3.4 \%$ & $\mathrm{X}$ \\
\hline$D I O_{l}^{0}$ & 50.0 & 90.0 & 50.0 & $\mathrm{X}$ \\
\hline$D R O_{l}^{0}$ & 60.0 & 10.0 & 6.6 & $\mathrm{X}$ \\
\hline$D P O_{l}^{0}$ & 51.8 & 60.0 & 10.0 & $\mathrm{X}$ \\
\hline$C C C_{l}^{0}$ & 58.2 & 40.0 & 46.6 & 144.8 \\
\hline$F C_{l}^{0}$ & 15.2 & 37.2 & 3.4 & 55.8 \\
\hline
\end{tabular}

Table 6b. Year-end data (after optimization).

\begin{tabular}{lcccc}
$l$ & Supplier & Wholesaler & Retailer & Total (SC) \\
$V_{l}^{k}$ & 869.2 & $5,666.5$ & 757.3 & $7,293.0$ \\
\hdashline$R_{l}^{k}$ & $1,219.6$ & 0.0 & 119.0 & $1,338.6$ \\
\hdashline$P_{l}^{k}$ & 901.0 & $3,777.7$ & 0.0 & $4,678.7$
\end{tabular}

\begin{tabular}{|c|c|c|c|c|}
\hline$l$ & Supplier & Wholesaler & Retailer & Total (SC) \\
\hline$W C_{l}^{k}$ & $1,187.7$ & $1,888.8$ & 876.3 & $3,952.8$ \\
\hline$C O G S_{l}^{k}$ & $6,345.0$ & $22,981.0$ & $5,528.0$ & $\mathrm{X}$ \\
\hline$R_{l}^{k}$ & $7,419.0$ & $29,792.0$ & $6,588.0$ & $\mathrm{X}$ \\
\hline$c_{l}^{k}$ & $8.2 \%$ & $4.7 \%$ & $3.4 \%$ & $\mathrm{X}$ \\
\hline$D I O_{l}^{k}$ & 50.0 & 90.0 & 50.0 & $\mathrm{X}$ \\
\hline$D R O_{l}^{k}$ & 60.0 & 0.0 & 6.6 & $\mathrm{X}$ \\
\hline$D P O_{l}^{k}$ & 51.8 & 60.0 & 0.0 & $\mathrm{X}$ \\
\hline$C C C_{l}^{k}$ & 58.2 & 30.0 & 56.6 & 144.8 \\
\hline$F C_{l}^{k}$ & 15.2 & 36.2 & 3.5 & 54.9 \\
\hline
\end{tabular}

Table 6c. Comparative change

\begin{tabular}{|c|c|c|c|c|}
\hline$l$ & Supplier & Wholesaler & Retailer & Total (SC) \\
\hline$I N V_{l}^{k}$ & $0 \%$ & $0 \%$ & $0 \%$ & $0 \%$ \\
\hline$A R_{l}^{k}$ & $0 \%$ & $-100 \%$ & $0 \%$ & $-38 \%$ \\
\hline$A P_{l}^{k}$ & $0 \%$ & $0 \%$ & $-100 \%$ & $-3 \%$ \\
\hline$W C_{l}^{k}$ & $0 \%$ & $-30 \%$ & $21 \%$ & $-14 \%$ \\
\hline$D I O_{l}^{k}$ & $0 \%$ & $0 \%$ & $0 \%$ & $\mathrm{X}$ \\
\hline$D R O_{l}^{k}$ & $0 \%$ & $-100 \%$ & $0 \%$ & $\mathrm{X}$ \\
\hline$D P O_{l}^{k}$ & $0 \%$ & $0 \%$ & $-100 \%$ & $\mathrm{X}$ \\
\hline$C C C_{l}^{k}$ & $0 \%$ & $-25 \%$ & $21 \%$ & $0 \%$ \\
\hline$F C_{l}^{k}$ & $0 \%$ & $-3 \%$ & $4 \%$ & $-2 \%$ \\
\hline
\end{tabular}

However, Table $6 \mathrm{~b}$ and Table $6 \mathrm{c}$ illustrate the decrease observed is comparatively insignificant and can only be achieved with unrealistic change in trade credit terms requiring immediate repayments.

\section{Discussion and conclusions}

The main goal of this paper was to develop a model of working capital optimization in collaborative supply chains and to describe how companies can benefit from collaboratively managing their financial flows at the supply chain level. The study indicates that companies do not 
yet use available opportunities adequately. By identifying possible ways of implementing CFC optimization within and outside the stability intervals of CCCs, the research illustrates approaches and targets for companies to overcome existing challenges by simultaneously using SCF instruments and inventory management practices.

The research contributes to existing SCM literature by focusing on financial flows and studying their optimization. The research integrates financial and supply chain perspectives on the involvement of WCM on the supply chain level.

Managerial actions towards working capital in collaborative supply chains are critical at the operational level for such operations as supply chain management, production, procurement and finance. The examined companies have gained knowledge of how to assess the cycle time of working capital at the intra-organizational level, but estimation of this at the inter-organizational level still causes difficulties for the companies involved in collaborative supply chains. This paper provides insights into a collaborative approach to WCM using an optimization CFC model by accurately assessing the length of the cycle time of working capital and the total financial costs associated with it. The paper provides mathematical justification of collaborative minimization of CFC on the grounds of using SCF solutions and implementing thorough inventory management strategies, bearing in mind that each company in a chain performance is constrained by liquidity and return target levels. The paper provides a basis for further research on the behavior of supply chain partners implementing specific SCF solutions by addressing the questions of strategic cooperation in pursuing shared objectives of total cost minimization and effective coalition structure.

There are two main theoretical implications of the paper that correspond to the main objectives justified by the empirical study. Current studies outline the importance of working capital management in supply chains because companies need to adjust their operations to the volatile economic and financial environment. First, the gap in research that connects the CCC approach and the threestage collaborative supply chains is filled by the development of the CFC concept. Secondly, the authors contributed to an improvement in the methodology of working capital assessment in collaborative supply chains by introducing the optimization model that provides a holistic view to the collaborative supply chains. The developed methodology is suitable for a three-stage collaborative supply chain and is applicable for usage for business, consultancy, 3PL or bank as an intermediary or the decision maker. Despite the fact, that the model provides a static solution to the problem of collaborative working capital management, it has the potential for further development of a dynamic algorithm.

Future research should seek to extend the context of this paper by investigating the possible imputation options for gained costs reduction on the grounds of cooperative games with a coalition structure, as there is a power asym- metry among players leading to possible lack of motivation to cooperate in the process of collaborative working capital management.

\section{References}

1. Kouvelis P., Chambers C., Wang H. Supply chain management research and production and operations management: Review, trends, and opportunities. Production and Operations Management. 2006;15(3):449-69. DOI: 10.1111/j.1937-5956.2006. tb00257.x

2. Gupta S., Dutta K. Modeling of financial supply chain. European Journal of Operational Research. 2011;211(1):47-56. DOI: 10.1016/j.ejor.2010.11.005

3. Deloof M. Does working capital management affect profitability of Belgian firms? Journal of Business Finance and Accounting. 2003;30(3-4):573-588. DOI: 10.1111/1468-5957.00008

4. García-Teruel P.J., Martínez-Solano P. Effects of working capital management on SME profitability. International Journal of Managerial Finance. 2007;3(2):164-177. DOI: 10.1108/17439130710738718

5. Johnson M., Templar S. The relationships between supply chain and firm performance: The development and testing of a unified proxy. International Journal of Physical Distribution and Logistics Management. 2011;41(2):88-103. DOI: 10.1108/09600031111118512

6. Viskari S., Pirttilä M., Kärri T. Improving profitability by managing working capital in the value chain of pulp and paper industry. International Journal of Managerial and Financial Accounting. 2011;3(4):348366. DOI: 10.1504/IJMFA.2011.043333

7. Viskari S., Kärri T. A model for working capital management in the inter-organisational context. International Journal of Integrated Supply Management. 2012;7(1-3):61-79. DOI: 10.1504/ IJISM.2012.051051

8. Matyac E. Financial supply chain management. Strategic Finance. 2015;96(9):62.

9. Gelsomino L. M., Mangiaracina, R., Perego, A., Tumino, A. Supply chain finance: a literature review. International Journal of Physical Distribution \& Logistics Management. 2016;46(4):348-366. DOI: 10.1108/IJPDLM-08-2014-0173

10. Hofmann E., Kotzab H. A Supply Chain-Oriented Approach of Working Capital Management. Journal of Business Logistics. 2010;31(2):305-330. DOI: 10.1002/j.2158-1592.2010.tb00154.x

11. Kouvelis P., Zhao W. Who should finance the supply chain? Impact of credit ratings on supply chain decisions. Manufacturing \& Service Operations Management. 2017;20(1):19-35. DOI: 10.1287/ msom.2017.0669 
12. Song H., Yu K., Lu Q. Financial service providers and banks' role in helping SMEs to access finance. International Journal of Physical Distribution and Logistics Management. 2018;48(1):69-92. DOI: 10.1108/IJPDLM-11-2016-0315

13. Martin J., Hofmann E. Involving financial service providers in supply chain finance practices: Company needs and service requirements. Journal of Applied Accounting Research. 2017;18(1):42-62. DOI: 10.1108/ JAAR-10-2014-0116

14. Protopappa-Sieke M., Seifert R.W. Benefits of working capital sharing in supply chains. Journal of the Operational Research Society. 2017;68(5):521-532. DOI: $10.1057 / \mathrm{s} 41274-016-0009-2$

15. Talonpoika A.M., Kärri T., Pirttilä M., Monto S. Defined strategies for financial working capital management. International Journal of Managerial Finance. 2016;12(3):277-294. DOI: 10.1108/IJMF-112014-0178

16. Xu X., Chen X., Jia F., Brown S., Gong Y., Xu Y. Supply chain finance: A systematic literature review and bibliometric analysis. International Journal of Production Economics. 2018;204:160-173. DOI: 10.1016/j.ijpe.2018.08.003

17. Silvestro R., Lustrato P. Integrating financial and physical supply chains: The role of banks in enabling supply chain integration. International Journal of Operations and Production Management. 2014;34(3):298-324. DOI: 10.1108/ IJOPM-04-2012-0131

18. Kroes J.R., Manikas A.S. Cash flow management and manufacturing firm financial performance: A longitudinal perspective. International Journal of Production Economics. 2014;148:37-50. DOI: 10.1016/j.ijpe.2013.11.008

19. Protopappa-Sieke M., Seifert R.W. Interrelating operational and financial performance measurements in inventory control. European Journal of Operational Research. 2010;204(3):439-448. DOI: 10.1016/j. ejor.2009.11.001

20. Gadde L.-E., Snehota I. Making the most of supplier relationships. Industrial Marketing Management, 2000;29(4):305-316. DOI: 10.1016/S00198501(00)00109-7

21. Håkansson H., Snehota I. No business is an island: The network concept of business strategy. Scandinavian Journal of Management. 1989;5(3):187220. DOI: 10.1016/0956-5221(89)90026-2

22. Simatupang T.M., Sridharan R. The collaborative supply chain. The International Journal of Logistics Management. 2002;13(1):15-30. DOI: 10.1108/09574090210806333

23. Frohlich M.T., Westbrook R. Arcs of integration: An international study of supply chain strategies. Journal of Operations Management. 2001;19(2):185-200. DOI: 10.1016/S0272-6963(00)00055-3
24. Barratt M. Understanding the meaning of collaboration in the supply chain. Supply Chain Management: An International Journal. 2004;9(1):3042. DOI: $10.1108 / 13598540410517566$

25. Kim S.W. An investigation on the direct and indirect effect of supply chain integration on firm performance. International Journal of Production Economics. 2009;119(2):328-346. DOI: 10.1016/j. ijpe.2009.03.007

26. Kirca A.H., Jayachandran S., Bearden W O. Market orientation: A meta-analytic review and assessment of its antecedents and impact on performance. Journal of Marketing. 2005;69(2):24-41. DOI: 10.1509/jmkg.69.2.24.60761

27. Beamon B.M. Supply chain design and analysis: Models and methods. International Journal of Production Economics. 1998;55(3):281-294. DOI: 10.1016/S0925-5273(98)00079-6

28. Håkansson H., Ford D. How should companies interact in business networks? Journal of Business Research. 2002; 55(2):133-139. DOI: 10.1016/S01482963(00)00148-X

29. Blome C., Paulraj A., Schuetz K. Supply chain collaboration and sustainability: A profile deviation analysis. International Journal of Operations and Production Management. 2014;34(5):639-663. DOI: 10.1108/IJOPM-11-2012-0515

30. Chen I.J., Paulraj A. Towards a theory of supply chain management: The constructs and measurements. Journal of Operations Management. 2004;22(2):119150. DOI: $10.1016 /$ j.jom.2003.12.007

31. Fairchild A. Intelligent matching: Integrating efficiencies in the financial supply chain. Supply Chain Management: An International Journal. 2005;10(4):244-248. DOI: $10.1108 / 13598540510612703$

32. Wuttke D.A., Blome C., Henke M. Focusing the financial flow of supply chains: An empirical investigation of financial supply chain management. International Journal of Production Economics. 2013;145(2):773-789. DOI: 10.1016/j.ijpe.2013.05.031

33. Fawcett S.E., Magnan G.M. The rhetoric and reality of supply chain integration. International Journal of Physical Distribution and Logistics Management. 2002;32(5):339-361. DOI: $10.1108 / 09600030210436222$

34. Cao M., Zhang Q. Supply chain collaboration: Impact on collaborative advantage and firm performance. Journal of Operations Management. 2011;29(3):163180. DOI: $10.1016 /$ j.jom.2010.12.008

35. Shi M., Yu W. Supply chain management and financial performance: Literature review and future directions. International Journal of Operations and Production Management. 2013; 33(10):1283-1317. DOI: 10.1108/IJOPM-03-2012-0112 
36. Gunasekaran A., Patel C., McGaughey R.E. A framework for supply chain performance measurement. International Journal of Production Economics. 2004;87(3):333-347. DOI: 10.1016/j. ijpe.2003.08.003

37. Hendricks K.B., Singhal V.R. The effect of supply chain glitches on shareholder wealth. Journal of Operations Management. 2003;21(5):501-522. DOI: 10.1016/j.jom.2003.02.003

38. Ramdas K., Spekman R.E. Chain or shackles: Understanding what drives supply-chain performance. Interfaces. 2000;30(4):3-21. DOI: 10.1287/inte.30.4.3.11644

39. Coyle J.J., Langley J.C., Novack R.A., Gibson B.J. Supply chain management: A logistics perspective. $9^{\text {th }}$ ed. Mason, OH: South-Western Publ.; 2013. 736 p.

40. Rokkan A.I., Heide J.B., Wathne K.H. Specific investments in marketing relationships: Expropriation and bonding effects. Journal of Marketing Research. 2003;40(2):210-224. DOI: 10.1509/jmkr.40.2.210.19223

41. Noordhoff C.S., Kyriakopoulos K., Moorman C., Pauwels P., Dellaert B.G. The bright side and dark side of embedded ties in business-to-business innovation. Journal of Marketing. 2011;75(5):34-52. DOI: 10.1509/jmkg.75.5.34

42. Seggie S.H., Griffith D.A., Jap S.D. Passive and active opportunism in interorganizational exchange. Journal of Marketing. 2013;77(6):73-90. DOI: 10.1509/jm.11.0529

43. Galaskiewicz J. Studying supply chains from a social network perspective. Journal of Supply Chain Management. 2011;47(1);4-8. DOI: 10.1111/j.1745493X.2010.03209.x

44. Flynn B.B., Huo B., Zhao X. The impact of supply chain integration on performance: A contingency and configuration approach. Journal of Operations Management. 2010;28(1):58-71. DOI: 10.1016/j. jom.2009.06.001

45. Paulraj A., Lado A.A., Chen I.J. Inter-organizational communication as a relational competency: Antecedents and performance outcomes in collaborative buyer-supplier relationships. Journal of Operations Management. 2008;26(1):45-64. DOI: 10.1016/j.jom.2007.04.001

46. Blackman I. D., Holland C., Westcott T. Motorola's global financial supply chain strategy. Supply Chain Management: An International Journal. 2013;18(2):132-147. DOI: $10.1108 / 13598541311318782$

47. Flynn B.B., Koufteros X., Lu G. On theory in supply chain uncertainty and its implications for supply chain integration. Journal of Supply Chain Management. 2016;52(3):3-27. DOI: 10.1111/ jscm. 12106

48. Malshe A., Agarwal M.K. From finance to marketing: The impact of financial leverage on customer satisfaction. Journal of Marketing. 2015;79(5):21-38. DOI: 10.1509/jm.13.0312

49. Stevens G., Johnson M. Integrating the supply chain ... 25 years on. International Journal of Physical Distribution and Logistics Management. 2016;46(1):19-42. DOI: 10.1108/ IJPDLM-07-2015-0175

50. Yousefi A., Pishvaee M.S. A fuzzy optimization approach to integration of physical and financial flows in a global supply chain under exchange rate uncertainty. International Journal of Fuzzy Systems. 2018;20(8):2415-2439. DOI: 10.1007/s40815-0180511-6

51. Cachon G.P., Lariviere M.A. Supply chain coordination with revenue-sharing contracts: Strengths and limitations. Management Science. 2005;51(1):30-44. DOI: 10.1287/mnsc.1040.0215

52. Fedorova E., Timofeev Y. Standards of financial stability of Russian companies: Industry-specific features. Korporativnye finansy = Journal of Corporate Finance Research. 2015;9(1):38-47. DOI: 10.17323/j. jcfr.2073-0438.9.1.2015.38-47 (In Russ.).

53. Enqvist J., Graham M., Nikkinen J. The impact of working capital management on firm profitability in different business cycles: Evidence from Finland. Research in International Business and Finance. 2014;32:36-49. DOI: 10.1016/j.ribaf.2014.03.005

54. Vázquez X.H., Sartal A., Lozano-Lozano L.M. Watch the working capital of tier-two suppliers: A financial perspective of supply chain collaboration in the automotive industry. Supply Chain Management: An International Journal. 2016;21(3):321-333. DOI: 10.1108/SCM-03-2015-0104

55. Chauhan G.S., Banerjee P. Financial constraints and optimal working capital - evidence from an emerging market. International Journal of Managerial Finance. 2018;14(1):37-53. DOI: 10.1108/IJMF-07-2016-0131

56. Jones M. Financial accounting. New York: John Wiley \& Sons; 2006. 544 p.

57. Pirttilä M., Viskari S., Lind L., Kärri T. Benchmarking working capital management in the interorganisational context. International Journal of Business Innovation and Research. 2014;8(2):119-136. DOI: DOI: 10.1504/IJBIR.2014.059529

58. Talonpoika A.M., Monto S., Pirttilä M., Kärri T. Modifying the cash conversion cycle: Revealing concealed advance payments. International Journal of Productivity and Performance Management. 2014;63(3):341-353. DOI: 10.1108/ IJPPM-12-2012-0130

59. Richards V.D., Laughlin E.J. A cash conversion cycle approach to liquidity analysis. Financial management. 1980;9(1):32-38. DOI: 10.2307/3665310

60. Shin H.H., Soenen L. Efficiency of working capital management and corporate profitability. Financial Practice and Education. 1998;8:37-45. 
61. Hutchison P.D., Farris M.T. II, Anders S.B. Cash-tocash analysis and management. The CPA Journal. 2007;77(8):42.

62. Cherkasova V., Chadin V. Working capital determinants in the concept of life cycle of the organization. Korporativnye finansy = Journal of Corporate Finance Research. 2015;9(2):79-99. DOI: 10.17323/j.jcfr.2073-0438.9.2.2015.79-99 (In Russ.).

63. Garanina T., Petrova O. Relationship between liquidity, cash conversion cycle and returns of Russian companies. Korporativnye finansy = Journal of Corporate Finance Research. 2015;9(1):5-21. DOI: 10.17323/j.jcfr.2073-0438.9.1.2015.5-21 (In Russ.).

64. Volkov D., Nikulin E. Current state and prospects for research on firm's working capital management. Korporativnye finansy = Journal of Corporate Finance Research. 2012;6(3):61-69. DOI: 10.17323/j.jcfr.20730438.6.3.2012.61-69 (In Russ.).

65. Garanina T.A., Belova O.A. Liquidity, cash conversion cycle and financial performance: Case of Russian companies. Investment Management and Financial Innovations. 2015;12(1):90-100.

66. Akkermans H., Van Wassenhove L N. Supply chain tsunamis: Research on low-probability, high-impact disruptions. Journal of Supply Chain Management. 2018;54(1):64-76. DOI: 10.1111/jscm. 12162

67. Yazdanfar D., Öhman P. The impact of cash conversion cycle on firm profitability: An empirical study based on Swedish data. International Journal of Managerial Finance. 2014;10(4):442-452. DOI: 10.1108/IJMF-12-2013-0137

68. Randall W.S., Farris M.T. II. Supply chain financing: using cash-to-cash variables to strengthen the supply chain. International Journal of Physical Distribution \& Logistics Management. 2009;39(8):669-689. DOI: 10.1108/09600030910996314

69. Gelsomino L.M., de Boer R., Steeman M., Perego A. An optimisation strategy for concurrent Supply Chain Finance schemes. Journal of Purchasing and Supply Management. 2018. DOI: 10.1016/j. pursup.2018.07.004

70. Margolis J.T., Sullivan K.M., Mason S.J., Magagnotti M. A multi-objective optimization model for designing resilient supply chain networks. International Journal of Production Economics. 2018;204:174-185. DOI: 10.1016/j.ijpe.2018.06.008

71. Yan N., He X., Liu Y. Financing the capitalconstrained supply chain with loss aversion: Supplier finance vs. supplier investment. Omega. 2018. DOI: 10.1016/j.omega.2018.08.003

72. Lazaridis I., Tryfonidis D. Relationship between working capital management and profitability of listed companies in the Athens stock exchange. Journal of Financial Management and Analysis. 2006;19(1).
73. Filbeck G., Krueger T.M. An analysis of working capital management results across industries. American Journal of Business. 2005;20(2):11-20. DOI: $10.1108 / 19355181200500007$

74. Marttonen S., Monto S., Kärri T. Profitable working capital management in industrial maintenance companies. Journal of Quality in Maintenance Engineering. 2013;19(4):429-446. DOI: 10.1108/ JQME-08-2013-0054

75. Viskari S., Lind L., Kärr, T., Schupp F. Using working capital management to improve profitability in the value chain of automotive industry. International Journal of Services and Operations Management. 2012;13(1):42-64. DOI: 10.1504/IJSOM.2012.048275

76. Viskari S., Ruokola A., Pirttilä M., Kärri T. Advanced model for working capital management: Bridging theory and practice. International Journal of Applied Management Science. 2012;4(1):1-17. DOI: 10.1504/ IJAMS.2012.044868

77. Ylä-Kujala A., Marttonen S., Kärri T., Sinkkonen T., Baglee D. Inter-organisational asset management: Linking an operational and a strategic view. International Journal of Process Management and Benchmarking. 2016;6(3):366-385. DOI: 10.1504/ IJPMB.2016.077631

78. Viskari S., Kärri T. A cycle time model for analysing the efficiency of working capital management in a value chain. International Journal of Business Performance and Supply Chain Modelling. 2013;5(3):221-238. DOI: 10.1504/ IJBPSCM.2013.055727

79. Stefanov S.M. Separable programming: Theory and methods. Berlin, Heidelberg: Springer Science \& Business Media; 2013. 314 p. (Applied Optimization Series. Vol. 53).

80. Lind L., Pirttilä M., Viskari S., Schupp F., Kärri T. Working capital management in the automotive industry: Financial value chain analysis. Journal of Purchasing and Supply Management. 2012;18(2):92100. DOI: $10.1016 /$ j.pursup.2012.04.003 